firoposal of the Insmance Bill to saddle the profession with a load shirked by the state is no new departure: it is a frigid application of the treatment meted out to the honorary staffs of all medical charities. That a community is boum to provicle adequately for its incligent sick is a principle owned a!ike by the coumon law of England, by statutes. and by morality ; and it is economically sound into the bargain. Nercitheless, as long as rioctors submit to exploitation, so long will the public evarle their obligations in respect of citizens mable to provirle for their medical requirements. The gratuitous operative and other work done by men of establisher reputation represents a large contribution in relief of the rates. and is recuited, as we were recently reminded, by a few commonplaces at annual meetings.

Other features of the out-jatient department ask attention, but I must close this part of my subject. The radical cause of hospital abase in the widle sense, when traced home. is found in the inherent defects of a bad system. No blame is attached to individual per'sons Jas' of all to hospital administrators; their assiduous and self-sacrificing labour entitles them to the gratiturle of all classes, and they and the staff alike are in the toils of il.2 system. The efforts of reformers in the past have argely failed, and were foredoomed to fail, because a paper warfare, supported by strong languase bit unsupported by effective action, conld yield no other result. In my opinion, any action, other than parliamentary, if it is soing to be successful, must come from the general body of the profession, and I believe we are now in a position "hich brings the possibility of reform within reach; anc the one remedy which many of us have been adrocating for years, and npon the securing of which all efforts should he concentrated, is to shut down the out-patient. department as now conducterl aud, using Sampson Gamgee's phrase, turn it into the " poor man's consulting room."

\section{The: OLTLOK.}

There is no more outstanding feature of contemporary medical affair's than the invasion of public practice and its aggressive march at an accelerating rate of speed. To what goal is the movement tending? From the considerations bearing on the answer to this question one weighty fact cmerges-the province of public practice is widlening at the expense of private practice; expansion of the former spells contraction of the latter; and when you compare the boundaries of the two in the medical Clomain fifty years ago with those marked on an up-toclate map, a substantial alteration in the balance of jower is apparent. For good or for ill, the activities of the private practitioner are getting hemmed in within cver-narrowing limits as legislative and social action absorbs more and more of his territory. Surrounded by a rising tide of State intervenition, the coastline of inclependent medical work is undergoing a process of gradual erosion, varied now and then by the sudden engulfiment of a landslicle, and the indications suggest that before long only the wealthy uplands will remain unsubmerged. Whilst this encroachment has been tolerably rapid, it has been on the whole so insidious that many of the profession, engrosser as they are in the exacting demands of practice, have not fully realized the character and extent of the influences which are conspiring to sap the very means of livelihood as now obtained. Failure to grasp the situation explains the apathy which has so long clelayed union and left the profession an easy prey to exploitation.

It is indisputable that there is a progressive tendency on the part of Governments to utilize the services of modical practitioners for national purposes, either by a direct link with a State department, or throngh statutory regulations. Many confluents help to swell the current movement, and thei: cumulative effect bears cogent witness to a higher public estimation of the functions of medicine and of their practical application under administrative control.

The monumental report of the Poor Law Commission has struck the minds of thoughtful men too forcibly to admit of the impression being obliterated. Both the great political parties are committer to a policy of social reform in which the scarlet thread of hygiene is intertwined, for it is agreed that the problem ean only be solved by a remedy containing an ingredient antidotal to the sickness, of which destitution and physical inefficiency are the offspring.

The ontlook to whicin the finger of recent and forcshadowed legislation ummistakably points, is a readjustment of the relations between medicine and the community resembling the reduction of a dislocation. And if, as so often in the past, the apparatus of medicine is ont of joint with the recognized wants of the age, then it may be sairl that forcible disturbance by parliamentary action is the historic mode of performing the indicated operation.

After taking paius to look at the situation steadily, one camnot escape the conclusion that the medical profession is swinging on the linge of fate in the direction of a national liealth service. Nor is the significance of the present position summed up by the mere statement that the strain of private general practice in the mass has increased in severity, and the returus decreaserl in value. The movement inports a great deal morc; it modifies the status of modicine, and is moring the profession to a new place in the body politic. By means of this transition, so it seems to me, whatever shall prove to be the true conception of the clinax to which civilization is on the road, medicine is destined in the near future to exert a forceful influence on the evolution of civilized society, greatly in excess of what has been seen or attempted hitherto.

\section{A TARGE FIBROCYSTIC TLMOUR DISTENDING} THE BLTTOCK.:

\section{BY JOHN D. MALCOLM, F.R.C.S.EDIN.,}

SURGEON TO THE SAMARIT.N FREE HOSPITAL.

$\Lambda$ woxus, aged 30 , the mother of one child 11 years old, was arlmitted to tie Samaritan Free Hospital on April 7th, 1911. Six years earlier she had difficulty in passing water, and was sent to a hospital under the care of an experienced surgeon, who has kindly informed me that she then had a lax cyst to the left of the vagina and another swelling behind the uterus on the same side. It was thought that there was a second vagina which might contain pus, and an incision was made into the lower swelling, but no pus was found and rery little fluid. The patient was discharged a month later, and was requested to return for further examination.

A fortnight after she went home a tumour came down in the vagina suddenly, without pain or haemorrhage, when she was stooping to clean a fireplace. A year later another surgeon of large experience was consulted, and I am indebted to him for the knowledge that the patient then had thrce swellings, respectively in the vagina, in the buttock, and in the abdomen. The growths were quite snall and did not interfere with the patient's movements at that time. Soon afterwards it was necessary to have the water drawn off by catheter, and except on this one occasion the patient did not consult any medical man from .July, 1906, until April, 1911, although she was unable to sit upon a chair for nearly four years.

Her story was that the swellings enlarged until the abdomen was as big as that of a woman seven months preguant, and the tumoin of the buttock was about half the size to which it ultimately attained. In August, 1910, she suffered from serere diarrhoea with blood in the stools, which continued for four rlays, and then the abdomen suddenly diminished almost to its proper size, and at the same time the lower tumour increased enormously in bulk. In the crening, after this change took place, the woman, in a fit of desperation, attacked the larger external tumour with the blunt cud of a liatpin, striking it many times until she became cxhausted, but apparently without breaking the skin. Next morning her bed was soaked in fluid, an escape of which occurred on other occasions and gave relief. Such a discharge was observed in the hospital, and it consisted of a serous exudation from the skin. After the size of the abrlomen diminished the patient was more comfortable, and she was always able to get about, although with increasing difficulty. Latterly she carried the external tumour in a piece of sheeting attached to her waist, but went out only after dark, because the tumour could not be hidden. Tho This case was described at the meeting of the Obstetrical and
Gyancolosical Section of the Royal Society of Medicine on October 5tl 
bowels were lept opan by laxative merlicine. After admission to hospital catheter specimens of the urine had a specific gravity of 1020 to 1025 and were sometimes free from albumen; sometimes they contained a trace, which was attributed to accidental contamination. Micturition and defaecation wore very difficult processes. The other systems were healthy, but the patient was rery thin and anaemic

When the woman was in bed on her hands and knees, partioularly if the legs were more or less out of sight behind the tumour and the bed clothes, the posterior part of her body appeared to rest upon the ench of the tumour, and the hind-quarters sometimes bore a close resemblance to those of a seal, so that the ignorant, especially if they caught only a glimpse of these parts, might easily have imagined that they had seen a creature half woman and half animal.

The larger external tumour was attached to the left side of the aums and to the left buttock. Its dimensions were is follows:

Greatest perpen.

dicular mes.

surement from

sacrum to

pubes ... ... $37 \div$ in.

Greatest hori-

zontal circum

ference

Simallest circuni-

ference of neck 29

It was entirely coreror

by skin, the distal part of which had a scaly appearance. as if from a prolonged, recentlyhealed eczema, and it was not broken any. where. In the recumbent position the auus was not een until the tumour was pulled away from the opposite buttock. It was so dragged upon that the inucous menibrane of the left side was exposed and very tender. When the patient stood erect the anus was still further pulled down and became visible below the right buttock. Digital examination. of the rectum caused severe pain, and the finger dicl not pass upwards into the pelvis, but downwards into the external mass of tissue. Percussion over the upper part of the timourr anjacent to the anus showed that there was an area of resonance measturing about 6 in. by 4 in., but varying in extent. The smaller external growth was attached to the left posterior aspect of the vagina well within the ostium, which was much distended. This tumour had a constriction near its base, and its measurements were:

$$
\begin{aligned}
& \text { In largest circumference } \\
& \text { In circumference of neck } \\
& \text { In lensth } \\
& \begin{array}{lll}
\ldots & \ldots & 14 \frac{1}{2} \mathrm{in} . \\
\ldots & \ldots & 9^{\circ}
\end{array}
\end{aligned}
$$

It was covered by mucous membrane, and its distal portion showed an extensive area of ulceration resembling that so commonly seen on a prolapsed uterus, which at the first glance it was supposed to be.

The vagina above the site of orisin of this tumour did not appear to be affected or eren displaced. The cervix uteri was in normal position, and the passage of a sound showed that the fundus was fairly well forward, but it conld not be felt by a hand upon the abdominal wall. 'The abdomen was uniformly but only slightly enlarged, and there was an area of clullness above the pubes rising nicarly to the umbilicus, but no definite tumour was marked ont by palpation. Behind and to the left of the vagina there was an abnormal ill-defined thickening of the tissues as if there was an isthmus of new growth extending from the internal to the external parts. The tumour protruding from the vagina seemed also to be attached to the narrow neck of tissue joining the other two growths. The Jarge external mass appeared to be cither cystic or a very soft solid containing cysts. It became obviously more tense when the patient strained. The vaginal tumour seemed to be a soft solid. 'The woman complained of no pain except in the anus when it was examined and when the bowels moved. She was wonderfully cheerful.

These conditions were seen by most of my colleagues and by others, amongst whom Sir Francis Champneys kindly examined the patient with me after she had been anaesthetized, and he kindly permits me to say that in his opinion the tumour was fibrocellular and subperitoneal, and that it occupied the abdomen and came down into the buttock. He also agreed that an attempt should be made to remove it. The very serious nature of the proposed operation was c'early explained to the patient, and she was anxious to have it performed.

The proceeding consisted of making a circular incision round the large cxternal tumour, well away: from its base and from the resonant area. The skin and a layer of fat were dividerl, and there was another well-marked, deeper capsule, within which Donglas's pouch was opened and a large mass of soft, shapeless material like a congeries of large coils of intestine matted together was exposed. This was not intestine and was not in the pouch of Douglas, but extraperitoneal, and it consisted of elongated thin-walled cavities containing, but not distended by, a thin clear, yellowish fluicl. The rectum was, easily, refined. and, aroided. there being a layer of loose connective tissue between it and the new growtli.

As it was clear that the tumours could not all be cnucleated from below, a. incision was made in the midllle line of the abclomen above the pubes, and a new growth was exposed very closely actherent to the left side of the bladder, which was raised high up towards the umbilicus. In separating the tumour the bladder was opened accidentally, although its position had been defined by passing a catheter into it. 'The opening was immediately closed, and was in itself unimportant. The abdominal tumour rose as high as the umbilicus. It was soft and somewhat flat, like a thick cake, and it lay altogether in front of the abdominal cavity. There was another smaller rounded growth behind the uterus. Neither of these expanded the broad ligament. All the tumours met in a narrow portion in the anterior part of the left side of the pelvis, and they were removed, two from above and two from below, with the exception of a small portion at their point of junction. After many vessels were ligatured the incisions were closed, the great cavity in the external wound being drained. Several of my colleagues kindly joined in adopting the usual measures for preventing shock, and the patient was put to bed alive, but the operation had been an exceedingly severe one, and she died aboüt half an hour later. 


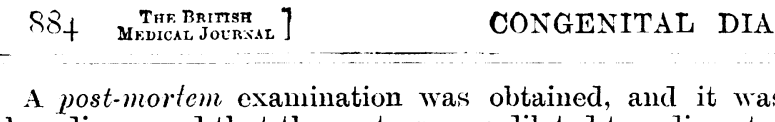
then discovered that the ureters were dilated to a diameter of half an inch, and the kidneys and their pelves were also enlarged. All the other organs appeared healthy, but anaemic. The remaining portion of the new growth was removed. This part was very narrow - not more than an inch in diameter-and it was held firmly against the anterior portion of the left side of the pelvic brim. There was no difficulty in separating it from any hollow viscus, or from the bone and muscles external to it, but it was adherent to, and apparentiy continuous with, the fascial structures which covered these muscles and which seemed to hold it in position. Its removal laid bare the ascending ramus of the pubic bone aurl the obturator vessels and nerve.

The parts removed at the operation, after much fluic had drained from them, weighed 39! lb. All the solid parts consisted of a soft, very cellular fibroid tissue, and Mr. Shattock discovered some unstriped muscle fibres in parts of the lower growth. The vaginal tumour has; been preserved in the Royal College of Surgeons. It is solid, and has shrunk very much. The larger external mass had a solid area abont 4 in. thick below the cystic part, and this-a portion of which was exhibited-lay on the table as a flat piece of tissue pliable in any direction. This solid part was clearly an expansion of some portion of the floor of the pelvis, and it was continuous with the inner capsule mentioned in describing the removal of the tumour, which undoubtedly was the greatly thickened pelvic floor expanded over the eystic portion of the growth.

It is not casy to form an opinion as to the site from which this remarkable tumour arose. A soft solid or crstic growth behind the uterus and another beside the vagina existed six year's before the patient was first seen by me, and it would appear that the paravacinal growth rapidly escaped through the cicatricial tissue former after an incision was macle into it from the vagina. Probably these were the first parts to develop. 'The anterior abdominal and the larger external masses seem to have consisted of an extension of new growth along the fascial planes upwards and downwards. The large cystic portion was attached to the upper surface of the new growth which developed along the fasciae of the pelvic floor and apparently invarled the muscralar tissues also. Probably the evstic portion was dragged or pushed down ont of the pelvis and abdomen during the straining excited by the attack of diarrhoea in August, 1910. The pouch of Douglas and its contents were necessarily risplaced as the pelvic floor descended. In the lower abdomen and about the brim of the pelvis the muscular structures forming the abdominal and pelvic wall were completely laid bare by the removal of the growth. Chiefly for this reason I would hazard the conjecture that the tumours grew from fascial tissue.

They showed no sign of malignancy except the obvious tendency to continuous growth, and the fact that the patient remained so comparatisely well arose from the absence of pressure ryon any inportant organ except the urinary tract. The urethra appears to have been first pressed upon, but the pressire seemed rather to diminish than otherwise as the growth enlarged. It any rate the need for catheterization ceased.

The great danger of the operation was due to the lone delay in operating, which allowed the abnormal renal condition to develop with a consequent anaemia and depreciation of resisting power in the body. and which necessitated an excessive manipulation in removing the growths.

When I saw the patient she was convinced that surgical interference offered the only hope of recovery. At an early staoc of the illness this was not so obvions, and it was most unfortmuate that she did not afford the fullest opportunities for considering her case to one of the surgeons whom she consulted in 1905 and 1906, or to some other surgeon at an earlier clate. When these tumours were of moderate size it would, in my opinion, have been sound practice to have examined them from within the abdomen, and this procedure would in all probability have been followed by their removal and by a complete cure of the patient.

\section{CONGENITAL DIAPHRAGMATIC HERNIA ASSOCIATLI) WITH EIBRIONIC: ORGANS.}

BY IASLIE RAWES, M.R.C'S.ENi., L.R.C.P.IAND., SAIISBTY GREN, HANTS.

THE following case is, I think, of interest not only from the fact that a diaphragmatic hernia was present, but also that the varions organs were under-developed.

A. F., a multipara, was delivered of a full term male child after a protracted labour. She was attended by a nurse, who gave the following history: For three days wrevious to the birth of the child the mother had been "feeling queer," but no definite labour pains had occurred, and " the waters had broken" twenty-four hours before the child was born. On questioning her as to the baby's gencral appearance at birth, she told me he was "very white," and she was twenty minutes before she could "get life into him." The child had not cried, lut had been moaning all the time as though in pain, and wonld not take the breast. nor had he passed any meconium. I saw the child the same day, and to ontward appearances he was normal. though pale: he was still moaning, but lay very still, with Jegs fully cxtcncled, and there was no

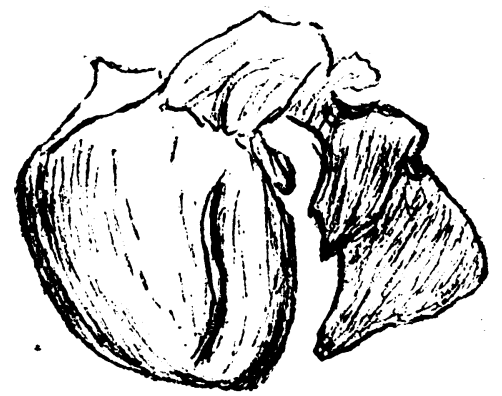

icinal size of heart and left lung. further symptom to guicle one in localizing the seat of pain, if pain it was. Respirations alpeared normal and regular, and the julse was also quito regular, but small. Very little haemorrhage harl ocenrred on cutting and tying the cord.

I left instructions that the baby was to be kept warm, ancl the mother should try and get him to take the breast. (On arrival at the house next morning $I$ was told the baby was dead, having lived only twenty hours.

\section{Necropsys.}

The following condition was found post mortem: The right lung was small, measuring about $3 \mathrm{in}$. by $1 \mathrm{in.}$, the greater part of that side of the chest being cmpty. The left lung was extremely small, and resembled a largo raisin, the wliole organ being about the sime of a halfpenny ; filling the remainder of the left side of the chest was the stomach and the whole of the small and large intestine. with the exception of the descending colon aud rectum. The small intestine was empty and massed together; the large bowel contained nueconium, which could be expressed per anum. The greater curvature of the stomach was directed upwards with the posterior surface of the organ lying anteriorly, so that the whole viscus was "upside down." The appendix was normal, and measured 1:1 in.

The heart was small and pusher over to the right side, althongh lying in close apposition to the left lung. The liver was normal in size and position. The pancreas and left kirlney were bound down together in the left renal regivin. Both kidneys resembled a small walnut in size, anil presented a rough fissured surface.

There was a large orening in the centre of the left siche of the diaphragm (with a smooth rounded edge), which would admit three fingers quite easily.

T'HE Honorary Secretaries of the Odontological Section of the Roval Society of Medicine are prepared to receive applications for grants in aid of scientific research in connexion with dentistry. The research work in question may be of any kind deemed likely to throw light on any of the problems comnected with dental surgery, and the conditions under which grants are made by the Section are of the kind nswally attaching to such grants by other bodies. Full information may be obtained on application to the Secretaries of the section at 15, Cavendish Square, Iondon, W. 